\title{
Preliminary Clinical Outcome of CXL in Keratoconus Patients
}

Dr. Tanuja Tanzin, $\mathrm{MS}^{1^{*}}$, Dr. Md. Anwar Hossain, $\mathrm{MS}^{2}$

${ }^{1}$ Consultant, Bangladesh Eye Hospital \& Associate Professor, Department of Ophthalmology, Chittagong Medical College, Chattogram, Bangladesh

${ }^{2}$ Registrar, Department of Ophthalmology, Chittagong Medical College, Chattogram, Bangladesh

Background: Corneal collagen cross-linking (CXL) is a promising method in the treatment of keratoconus (KCN); however, long-term results of this treatment modality are under-represented in the literature. Objective: In this study our main goal is to evaluate the preliminary clinical outcome of CXL in Keratoconus patients in Bangladesh after 1 year follow up. Method: This retrospective observational type of study was conducted among 40 patients who fulfilled criteria from Bangladesh Eye Hospital, Chittagong January 2014 to January 2019. Results: During the study, most of the patients belong to 31-40 years age group, 48\%. Treated eyes showed a flattening of the steepest simulated keratometry value (K-max) by an average of 0.74 diopters $(\mathrm{D})(\mathrm{P}=.004)$ at 3 months, $0.92 \mathrm{D}(\mathrm{P}=.002)$ at 6 months, and $1.45 \mathrm{D}(\mathrm{P}=.002)$ at 12 months. A trend toward improvement in best spectacle-corrected visual acuity was also observed. In the control eyes, mean K-max steepened by $0.60 \mathrm{D}(\mathrm{P}=.041)$ after 3 months, by $0.60 \mathrm{D}(\mathrm{P}=.013)$ after 6 months, and by $1.28 \mathrm{D}(\mathrm{P}<.0001)$ after 12 months. Best spectacle-corrected visual acuity decreased by $\log$ MAR 0.003 $(\mathrm{P}=.883)$ over 3 months, $0.056(\mathrm{P}=.092)$ over 6 months, and $0.12(\mathrm{P}=.036)$ over 12 months. Conclusion: From our study we can conclude that, $\mathrm{CXL}$ could be considered as a promising first line treatment for most patients with progressive $\mathrm{KCN}$, especially considering our encouraging long-term results.

Keywords: Keratoconus, cornel collagen cross linking (CXL), corneal condition.

Copyright @ 2020: This is an open-access article distributed under the terms of the Creative Commons Attribution license which permits unrestricted use, distribution, and reproduction in any medium for non-commercial use (NonCommercial, or CC-BY-NC) provided the original author and source are credited.

\section{INTRODUCTION}

Keratoconus is a relatively common ectatic corneal condition causing significant visual disability. It is characterized by progressive irregular myopic astigmatism with central corneal thinning and protrusion [1]. Keratoconus affects both eyes in the majority of cases but may be markedly asymmetric. The Collaborative Longitudinal Evaluation of Keratoconus (CLEK) Group has presented findings related to keratoconus in a large cohort of patients from diverse ethnicities in the USA [2]. Similarly the Dundee University Group has published a longitudinal study on a more homogenous population from Scotland [4]. However, characteristics of keratoconus in Asian populations seem to vary from those reported from other ethnic groups. In a population-based cohort analysis, the Central India Eye and Medical Study reported the prevalence of keratoconus in central India to be $1.4 \%$ [5]. The incidence of keratoconus has been shown to range from 1 in 4,000 to 5,100 persons per year in Asian populations.
Several studies support the role of corneal collagen cross-linking $(C X L)$, which is a therapeutic procedure aiming at increasing the corneal stiffness in the keratoconus eyes; however, there is a paucity of long-term data. According to some studies long term efficacy and safety of CXL are uncertain; indeed, there are few publications with more than 5 years of follow up $[3,4]$.

In this study our main goal is to evaluate the preliminary clinical outcome of CXL in Keratoconus patients in Bangladesh.

\section{OBJECTIVE \\ General Objective}

- To assess the preliminary clinical outcome of CXL in Keratoconus patients in Bangladesh.

\section{Specific Objective}

- To detect clinical characteristics of the patients

- To identify post-operative findings in patients. 


\section{Methodology}

\begin{tabular}{|l|l|}
\hline Type of study & Retrospective observational study \\
\hline Place of study & Bangladesh Eye Hospital, Chittagong \\
\hline Study period & January 2014 to January 2019. \\
\hline Study population & 40 patients included in the study who were fulfilled criteria. \\
\hline Sampling technique & Purposive \\
\hline
\end{tabular}

\section{Study Procedure}

\section{During the Study}

Face to face interview of the participants were conducted with the semi-structured, pre-tested questionnaire. The interview was conducted anonymously and privately as much as possible. Before preceding the data collection, the detail of the study was explicitly explained to each eligible respondent and informed written consents from the respondents were obtained.

Corneal collagen crosslinking was performed using $0.1 \%$ riboflavin (in $20 \%$ dextran $\mathrm{T} 500$ ) and ultraviolet A (UVA) irradiation $(370 \mathrm{~nm}, 3 \mathrm{~mW} / \mathrm{cm} 2$, $30 \mathrm{~min})$ under sterile conditions. The UV-X 1000 machine (IROC Innocross AG, Zurich, Switzerland) and the Innocross-R riboflavin isotonic solution (riboflavin 5-phosphate $(0.1 \%)$ plus $20 \%$ Dextran T500 in $2 \mathrm{~mL}$ syringes) were used. The procedure was performed under general anaesthesia in very young patients and under topical anaesthesia in older patients. After anaesthesia, a lid speculum was inserted and the corneal epithelium was soaked with $20 \%$ alcohol for 40 seconds. The epithelial tissue was then removed in a $9.0 \mathrm{~mm}$ diameter area with a cellulose surgical spear to allow penetration of riboflavin into the corneal stroma. Thereafter, the photosensitizer $0.1 \%$ riboflavin was applied ( 2 to 3 drops every 3 minutes) to the cornea for 30 minutes before irradiation to allow sufficient saturation of the stroma.

Corneal soaking of riboflavin was assessed and then the central $8.0 \mathrm{~mm}$ cornea was exposed to UVA light (wavelength of $370 \mathrm{~nm}$ and irradiance of $3 \mathrm{~mW} / \mathrm{cm} 2$ ) for 30 minutes. Throughout the UVA exposure, riboflavin solution was instilled (2 to 3 drops every 3 minutes). Upon completion of treatment, the eye was washed with balanced salt solution and antibiotic eye drops (ofloxacin $0.3 \%$ ) and steroid eye drops (dexamethasone $0.1 \%$ ) were applied. A bandage contact lens was placed in the eye until complete reepithelialization. Subsequent follow-up examinations were performed at 1 week and thereafter at $1,6,12$, months and annually thereafter. The BSCVA, corneal topography, and central corneal thickness (CCT) were recorded at each visit.

\section{Data Analysis}

Data were entered in the template of Statistical program, SPSS-15 after necessary editing and coding. Descriptive statistics were generated for sociodemographic variables and were presented with relative frequency.

\section{RESULTS}

In Table-1 shows age distribution of patients where most of the patients belong to 31-40 years age group, $48 \%$. The following table is given below in detail:

Table-1: Age distribution of patients

\begin{tabular}{|l|l|}
\hline Age group in years & Percentage \\
\hline$(>20)$ years & $36 \%$ \\
\hline$(21-30)$ years & $48 \%$ \\
\hline$(31-40)$ years & $11 \%$ \\
\hline$>40$ years & $5 \%$ \\
\hline Total $=$ & $100 \%$ \\
\hline
\end{tabular}

In Figure-1 shows distribution of patients according to the gender where $57 \%$ patients were male, which was $14 \%$ higher than female. The following figure is given below in detail:

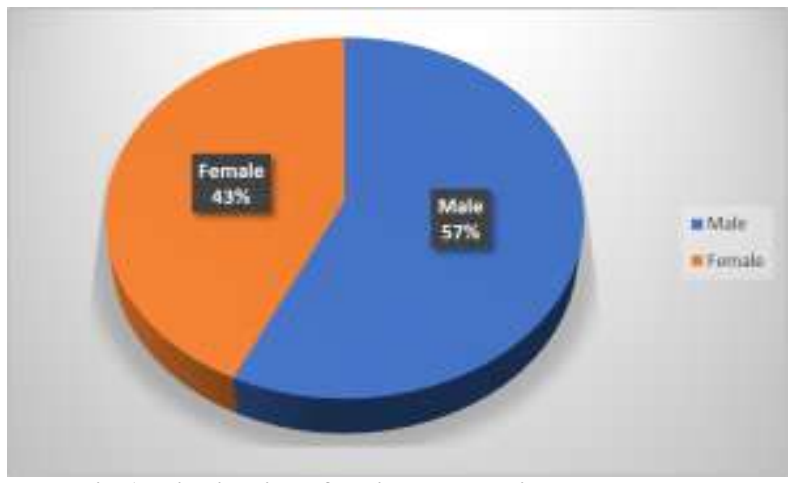

Fig-1: Distribution of patients according to the gender 
In Table-2 shows comparison of BCVA baseline and last follow-up of 30 keratoconic eyes patients after corneal collagen crosslinking (CXL) with a 1-year follow-up. Where after CXL most of the patient's log MAR BSCVA improved. The following table is given below in detail:

Table-2: Comparison of BCVA baseline and last follow-up of 30 keratoconic eyes patients after corneal collagen crosslinking (CXL)

\begin{tabular}{|c|c|c|}
\hline Before CXL & Before CXL, BCVA & After CXL, BCVA \\
\hline $\mathrm{R} / \mathrm{E}$ & $6 / 18$ & $6 / 12$ \\
\hline $\mathrm{L} / \mathrm{E}$ & $6 / 12$ & $6 / 9$ \\
\hline $\mathrm{R} / \mathrm{E}$ & $6 / 18$ & $6 / 12$ \\
\hline $\mathrm{R} / \mathrm{E}$ & $6 / 12$ & $6 / 9$ \\
\hline $\mathrm{L} / \mathrm{E}$ & $6 / 18$ & $6 / 12$ \\
\hline $\mathrm{L} / \mathrm{E}$ & $6 / 24$ & $6 / 12$ \\
\hline $\mathrm{R} / \mathrm{E}$ & $6 / 18$ & $6 / 12$ \\
\hline $\mathrm{L} / \mathrm{E}$ & $6 / 12$ & $6 / 9$ \\
\hline $\mathrm{R} / \mathrm{E}$ & $6 / 12$ & $6 / 9$ \\
\hline $\mathrm{R} / \mathrm{E}$ & $6 / 18$ & $6 / 12$ \\
\hline $\mathrm{L} / \mathrm{E}$ & $6 / 18$ & $6 / 12$ \\
\hline $\mathrm{L} / \mathrm{E}$ & $6 / 18$ & $6 / 12$ \\
\hline $\mathrm{R} / \mathrm{E}$ & $6 / 12$ & $6 / 9$ \\
\hline $\mathrm{L} / \mathrm{E}$ & $6 / 12$ & $6 / 9$ \\
\hline $\mathrm{R} / \mathrm{E}$ & $6 / 12$ & $6 / 9$ \\
\hline $\mathrm{R} / \mathrm{E}$ & $6 / 24$ & $6 / 12$ \\
\hline $\mathrm{L} / \mathrm{E}$ & $6 / 24$ & $6 / 12$ \\
\hline $\mathrm{L} / \mathrm{E}$ & $6 / 18$ & $6 / 12$ \\
\hline $\mathrm{R} / \mathrm{E}$ & $6 / 18$ & $6 / 12$ \\
\hline $\mathrm{L} / \mathrm{E}$ & $6 / 18$ & $6 / 12$ \\
\hline $\mathrm{R} / \mathrm{E}$ & $6 / 12$ & $6 / 9$ \\
\hline $\mathrm{R} / \mathrm{E}$ & $6 / 12$ & $6 / 9$ \\
\hline $\mathrm{L} / \mathrm{E}$ & $6 / 24$ & $6 / 12$ \\
\hline $\mathrm{L} / \mathrm{E}$ & $6 / 24$ & $6 / 12$ \\
\hline $\mathrm{R} / \mathrm{E}$ & $6 / 18$ & $6 / 12$ \\
\hline $\mathrm{L} / \mathrm{E}$ & $6 / 18$ & $6 / 12$ \\
\hline $\mathrm{L} / \mathrm{E}$ & $6 / 12$ & $6 / 9$ \\
\hline $\mathrm{R} / \mathrm{E}$ & $6 / 12$ & $6 / 9$ \\
\hline $\mathrm{L} / \mathrm{E}$ & $6 / 18$ & $6 / 12$ \\
\hline $\mathrm{R} / \mathrm{E}$ & $6 / 12$ & $6 / 9$ \\
\hline $\mathrm{R} / \mathrm{E}$ & $6 / 12$ & $6 / 9$ \\
\hline $\mathrm{L} / \mathrm{E}$ & $6 / 18$ & $6 / 12$ \\
\hline $\mathrm{R} / \mathrm{E}$ & $6 / 18$ & $6 / 12$ \\
\hline $\mathrm{L} / \mathrm{E}$ & $6 / 12$ & $6 / 9$ \\
\hline $\mathrm{R} / \mathrm{E}$ & $6 / 18$ & $6 / 12$ \\
\hline $\mathrm{R} / \mathrm{E}$ & $6 / 12$ & $6 / 9$ \\
\hline $\mathrm{L} / \mathrm{E}$ & $6 / 18$ & $6 / 12$ \\
\hline $\mathrm{L} / \mathrm{E}$ & $6 / 24$ & $6 / 12$ \\
\hline $\mathrm{R} / \mathrm{E}$ & $6 / 18$ & $6 / 12$ \\
\hline $\mathrm{L} / \mathrm{E}$ & $6 / 12$ & $6 / 9$ \\
\hline $\mathrm{R} / \mathrm{E}$ & $6 / 12$ & $6 / 9$ \\
\hline $\mathrm{R} / \mathrm{E}$ & $6 / 18$ & $6 / 12$ \\
\hline
\end{tabular}

In Table-3 shows pre- and post-crosslinking data for treated eyes where there was a significant reduction in keratometry values following crosslinking. The following table is given below in detail: 
Tanuja Tanzin \& Anwar Hossain., Sch J App Med Sci, August, 2020; 8(8): 1818-1822

Table-3: Pre- and post-crosslinking data for treated eyes

\begin{tabular}{|c|c|c|c|c|c|c|c|c|}
\hline $\begin{array}{l}\text { Before } \\
\text { CXL K1 }\end{array}$ & $\begin{array}{l}\text { Before } \\
\text { CXL K2 }\end{array}$ & $\begin{array}{l}\text { Before } \\
\text { CXL } \\
\text { Kmax } \\
\end{array}$ & $\begin{array}{l}\text { Before CXL, } \\
\text { thinnest local }\end{array}$ & $\begin{array}{l}\text { After } \quad \text { CXL } \\
\text { K1, 1 year } \\
\text { follow up }\end{array}$ & $\begin{array}{lr}\text { After } & \text { CXL } \\
\text { K2,1 year } & \text { yollow up } \\
\text { follow }\end{array}$ & $\begin{array}{l}\text { After } \\
\text { CXL, } \\
\text { Kmax }\end{array}$ & $\begin{array}{l}\text { After CXL, } \\
\text { thinnest } \\
\text { local }\end{array}$ & $\begin{array}{l}\text { Before } \\
\text { CXL K1 }\end{array}$ \\
\hline 52.1 & 53.6 & $57.8 \mathrm{D}$ & 394 & 52.7 & 53.2 & 58.9D & 394 & 52.1 \\
\hline 49.9 & 53.2 & 58.7D & 407 & 49.4 & 52.3 & 57.7D & 364 & 49.9 \\
\hline 52.0 & 53.7 & 57.9D & 395 & 52.5 & 53.2 & $58.8 \mathrm{D}$ & 395 & 52.0 \\
\hline 49.8 & 53.2 & 58.7D & 407 & 49.4 & 52.3 & 57.7D & 364 & 49.8 \\
\hline 45.2 & 52 & $58.1 \mathrm{D}$ & 405 & 52.0 & 53.7 & $57.9 \mathrm{D}$ & 395 & 45.2 \\
\hline 52.0 & 53.7 & 57.9D & 395 & 52.1 & 53.6 & $57.8 \mathrm{D}$ & 394 & 52.0 \\
\hline $6 / 12$ & 52.1 & $53.6 \mathrm{D}$ & $\begin{array}{l}57.8 \\
\end{array}$ & 52.7 & 53.2 & 58.9D & 394 & $6 / 12$ \\
\hline $6 / 12$ & 52.1 & $53.6 \mathrm{D}$ & $\begin{array}{l}57.8 \\
\end{array}$ & 52.7 & 53.2 & 58.9D & 394 & $6 / 12$ \\
\hline 49.8 & 53.2 & 58.7D & 407 & 49.4 & 52.3 & 57.7D & 364 & 49.8 \\
\hline 49.8 & 53.2 & 58.7D & 407 & 49.4 & 52.3 & 57.7D & 364 & 49.8 \\
\hline 49.8 & 53.2 & 58.7D & 407 & 49.4 & 52.3 & 57.7D & 364 & 49.8 \\
\hline 52.0 & 53.7 & 57.9D & 395 & 52.5 & 53.2 & $58.8 \mathrm{D}$ & 395 & 52.0 \\
\hline 52.0 & 53.7 & 57.9D & 395 & 52.5 & 53.2 & $58.8 \mathrm{D}$ & 395 & 52.0 \\
\hline 52.0 & 53.7 & 57.9D & 395 & 52.5 & 53.2 & $58.8 \mathrm{D}$ & 395 & 52.0 \\
\hline 45.2 & 52 & 58.1D & 405 & 52.0 & 53.7 & 57.9D & 395 & 45.2 \\
\hline 45.2 & 52 & 58.1D & 405 & 52.0 & 53.7 & 57.9D & 395 & 45.2 \\
\hline 49.9 & 53.2 & 58.7D & 407 & 49.4 & 52.3 & 57.7D & 364 & 49.9 \\
\hline 49.9 & 53.2 & 58.7D & 407 & 49.4 & 52.3 & 57.7D & 364 & 49.9 \\
\hline 49.9 & 53.2 & $58.7 \mathrm{D}$ & 407 & 49.4 & 52.3 & $57.7 \mathrm{D}$ & 364 & 49.9 \\
\hline 52.1 & 53.6 & $57.8 \mathrm{D}$ & 394 & 52.7 & 53.2 & 58.9D & 394 & 52.1 \\
\hline 52.1 & 53.6 & $57.8 \mathrm{D}$ & 394 & 52.7 & 53.2 & 58.9D & 394 & 52.1 \\
\hline 45.2 & 52 & 58.1D & 405 & 52.0 & 53.7 & $57.9 \mathrm{D}$ & 395 & 45.2 \\
\hline 45.2 & 52 & 58.1D & 405 & 52.0 & 53.7 & 57.9D & 395 & 45.2 \\
\hline 49.9 & 53.2 & 58.7D & 407 & 49.4 & 52.3 & $57.7 \mathrm{D}$ & 364 & 49.9 \\
\hline 49.9 & 53.2 & 58.7D & 407 & 49.4 & 52.3 & 57.7D & 364 & 49.9 \\
\hline 52.1 & 53.6 & $57.8 \mathrm{D}$ & 394 & 52.7 & 53.2 & $58.9 \mathrm{D}$ & 394 & 52.1 \\
\hline 52.1 & 53.6 & $57.8 \mathrm{D}$ & 394 & 52.7 & 53.2 & 58.9D & 394 & 52.1 \\
\hline 49.9 & 53.2 & 58.7D & 407 & 49.4 & 52.3 & 57.7D & 364 & 49.9 \\
\hline 52.1 & 53.6 & $57.8 \mathrm{D}$ & 394 & 52.7 & 53.2 & $58.9 \mathrm{D}$ & 394 & 52.1 \\
\hline 52.1 & 53.6 & 57.8D & 394 & 52.7 & 53.2 & 58.9D & 394 & 52.1 \\
\hline 49.9 & 53.2 & 58.7D & 407 & 49.4 & 52.3 & $57.7 \mathrm{D}$ & 364 & 49.9 \\
\hline 49.9 & 53.2 & 58.7D & 407 & 49.4 & 52.3 & 57.7D & 364 & 49.9 \\
\hline 52.1 & 53.6 & $57.8 \mathrm{D}$ & 394 & 52.7 & 53.2 & 58.9D & 394 & 52.1 \\
\hline 49.9 & 53.2 & 58.7D & 407 & 49.4 & 52.3 & $57.7 \mathrm{D}$ & 364 & 49.9 \\
\hline 52.0 & 53.7 & 57.9D & 395 & 52.5 & 53.2 & $58.8 \mathrm{D}$ & 395 & 52.0 \\
\hline 49.8 & 53.2 & 58.7D & 407 & 49.4 & 52.3 & $57.7 \mathrm{D}$ & 364 & 49.8 \\
\hline 45.2 & 52 & 58.1D & 405 & 52.0 & 53.7 & 57.9D & 395 & 45.2 \\
\hline 52.0 & 53.7 & 57.9D & 395 & 52.1 & 53.6 & $57.8 \mathrm{D}$ & 394 & 52.0 \\
\hline $6 / 12$ & 52.1 & $53.6 \mathrm{D}$ & 57.8 & 52.7 & 53.2 & 58.9D & 394 & $6 / 12$ \\
\hline
\end{tabular}

In Figure-2 shows corneal topography showing a reduction in keratometry after CXL where at 18 months after CXL, there was a reduction in $K 2$ by $1.8 \mathrm{D}$ in the treated eye. The following figure is given below in detail:
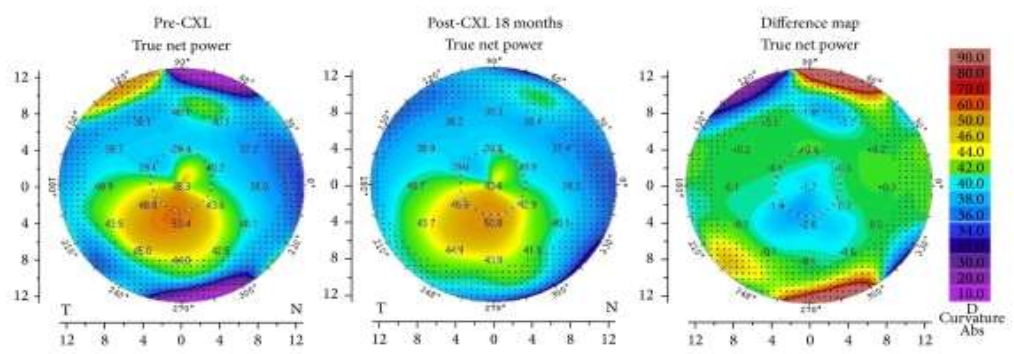

Fig-2: corneal topography showing a reduction in keratometry after CXL Source by: https://www.hindawi.com/journals/bmri/2014/140461/ 


\section{DISCUSSION}

In one study reported that, there was a higher percentage of male subjects indicating a trend toward earlier diagnosis in this gender. Mean age at the time of diagnosis of keratoconus is typically in the second decade of life [7].

In our series, most of the patients belong to 3140 years age group, $48 \%$. Also, $57 \%$ patients were male, which was $14 \%$ higher than female. Which was quite similar to other study [8].

One study reported that, younger age at diagnosis could mean that the condition has earlier onset and faster progression in Asian populations reflecting variability of the disease process [9].

Similar to the other studies, there were very few patients over 40 years of age in our series [7, 8]. Keratoconus patients demonstrate a period of stability 8 to 12 years after diagnosis, thus, most of them may seek care with local ophthalmologists/contact lens practitioners [5].

In one study found that, the mean preoperative spherical refractive error was $-1.46 \pm 2.31$ diopters, the mean cylinder was $-3.70 \pm 1.81$ diopters and mean spherical equivalent (SE) was $-3.25 \pm 2.44$ diopters. Postoperatively the mean sphere was $-1.34 \pm 2.22$ diopters, the mean cylinder was $-3.12 \pm 1.86$ diopters and the mean SE was $-2.90 \pm 2.40$ diopters [9]. Which was quite similar to our study. Another study documented a decrease in $\mathrm{K}$ max by an average of -2.57 $\mathrm{D}$ in their cohort of patients [10].

Another article reported significant improvement of -0.15 Log MAR in BSCVA at 36 months. They did not detect any change in spherical equivalent or cylindrical component of the subjective refraction. They also reported an improvement in $\mathrm{Kmax}$ by a mean of $-0.74 \mathrm{D}$ after 12 months in cross linked group and progression by a mean of $+1.28 \mathrm{D}$ [11]

\section{CONCLUSION}

From our study we can conclude that, CXL could be considered as a promising first line treatment for most patients with progressive $\mathrm{KCN}$, especially considering our encouraging results.

\section{REFERENCE}

1. Bawazeer AM, Hodge WG, Lorimer B. Atopy and keratoconus: a multivariate analysis. $\mathrm{Br} \mathrm{J}$ Ophthalmol. 2000; 84:834-836.
2. Szczotka LB, Barr JT, Zadnik K the CLEK Study Group. A summary of the findings from the Collaborative Longitudinal Evaluation of Keratoconus (CLEK) study. Optometry. 2001; 72:574-587.

3. Weed KH, McEwen CJ, Giles T, Low J, McGhee CNJ. The Dundee University Scottish Keratoconus Study: Demographics, corneal signs, associated diseases, and eye rubbing. Eye (Lond). 2008; 22:534-541.

4. Jonas J, Nangia V, Matin A, Kulkarni M, Bhojwani K. Prevalence and associations of keratoconus in rural maharashtra in central India: the central India eye and medical study. Am J Ophthalmol. 2009; 148:760-765.

5. Georgiou T, Funnell CL, Cassels-Brown A, O'Conor R. Influence of ethnic origin on the incidence of keratoconus and associated atopic disease in Asians and white patients. Eye (Lond). 2004; 18:379-383.

6. Pearson AR, Soneji B, Sarvananthan N, SandfordSmith JH. Does ethnic origin influence the incidence or severity of keratoconus? Eye (Lond). 2000; $14: 625-628$ https://www.hindawi.com/journals/bmri/2014/140 461/

7. O'Brart DP, Patel P, Lascaratos G, Wagh VK, Tam C, Lee J, O'Brart NA. Corneal cross-linking to halt the progression of keratoconus and corneal ectasia: seven-year follow-up. American Journal of Ophthalmology. 2015 Dec 1;160(6):1154-63.

8. Saffarian L, Khakshoor H, Zarei-Ghanavati M, Esmaily H. Corneal Crosslinking for Keratoconus in Iranian Patients: Outcomes at 1 year following treatment. Middle East African journal of ophthalmology. 2010 Oct;17(4):365-68.

9. O'Brart DP, Chan E, Samaras K, Patel P, Shah SP. A randomised, prospective study to investigate the efficacy of riboflavin/ultraviolet A $(370 \mathrm{~nm})$ corneal collagen cross-linkage to halt the progression of keratoconus. British Journal of Ophthalmology. 2011 Nov 1;95(11):1519-24.

10. Wittig-Silva C, Chan E, Islam FM, Wu T, Whiting M, Snibson GR. A randomized, controlled trial of corneal collagen cross-linking in progressive keratoconus: three-year results. Ophthalmology. 2014 Apr 1;121(4):812-21.

11. O'Brart DP, Kwong TQ, Patel P, McDonald RJ, O'Brart NA. Long-term follow-up of riboflavin/ultraviolet A $(370 \mathrm{~nm})$ corneal collagen cross-linking to halt the progression of keratoconus. British Journal of Ophthalmology. 2013 Apr 1;97(4):433-7. 